\title{
The effect of job demand, work exhaustion, and job satisfaction on turnover intention
}

\author{
Phuong V. Nguyen ${ }^{\mathrm{a}, \mathrm{b}^{*}}$, Huynh Thi Sa Do ${ }^{\mathrm{a}, \mathrm{b}}$ and Binh Tan Mai ${ }^{\mathrm{a}, \mathrm{b}}$
}

${ }^{a}$ Center for Public Administration, International University, VNU-HCMC, Vietnam

${ }^{b}$ Vietnam National University, Ho Chi Minh City, Vietnam

\section{H R O N I C L E}

\section{Article history:}

Received: May 30, 2020

Received in revised format:

May 302020

Accepted: June 19, 2020

Available online:

June 19, 2020

Keywords:

Turnover intention

Civil service employees

Public management

\section{A B S T R A C T}

This study investigates the influences of job demands, work exhaustion, and job satisfaction on turnover intention among Vietnamese civil service employees. Additionally, the correlation between social support and job motivation with job satisfaction and turnover intention are also examined. A structural equation modeling technique was employed to conduct the data analysis with a survey of 318 civil service employees working in 10 different departments in the public sector. The results reveal that job demands had a positive association with both work exhaustion and turnover intention. In contrast, work exhaustion and job satisfaction are both significantly related to turnover intention. Surprisingly, the adverse effects of social support and job motivation on work exhaustion are insignificant. In addition to theoretical highlights, our study provides practical implications and managerial recommendations for government agencies in the public sector to minimize the turnover rate and retain their employees.

\section{Introduction}

Civil service employees, who work directly with citizens in need of public services, are expected to interpret the abstract notions of public policy to provide information that best serves the needs and queries of citizens (Prottas, 1978). Their understanding of the public and service systems is an exceptionally essential resource that may not be easily replaced (Balfour \& Neff, 1993; Lipsky, 2010; Weissert, 1994; Kurniawaty et al., 2019), contributing to the success of public policy implementation. Civil servant turnover requires considerable resources from government agencies to recruit and train new employees (Griffeth \& Hom, 2001; Wright \& Kim, 2004), and results in disrupted relationships with citizens and the loss of cumulative knowledge of former employees (Kim, 2015). In recent years, the Vietnamese government has striven to improve the public service sector to create a more convenient and pleasant experience among citizens. For example, government agencies have introduced new approaches to procedures and performance evaluations, improvements in quality of working systems, and application of up-to-date information technology. However, there remain obstacles that require a huge effort from the government to further enhance public service management strategy. Notably, the provision of public services has not been highly valued due to the obstructions and impacts of bureaucracy, especially the complicated administrative procedures and lack of professionalism among frontline civil service employees. In addition, the necessary information about specific systems and methods has not been clearly and transparently disclosed, which causes difficulties and complexities in execution. Legal documents regulating administrative procedures are still complicated, overlapping, and confusing, with multiple interpretations that take an abundance of time and effort to complete, causing inconvenience for both citizens and civil service employees. As a result, civil service employees are often overwhelmed and endure significant pressure because the workload is both diverse and enormous. The repetition of tasks and "red tape" may also decrease the motivation and engagement of civil service employees. Previous studies show that civil service employees tend to experience emotional exhaustion, as their job involves "processing" people. Hence, their concern for the job is likely to increase, causing a high level of stress (Cordes \& Dougherty, 
1993); eventually, it leads to turnover intention due to job stress and work exhaustion (J. Kim, 2015; S. Kim, 2005; S. Kim \& Wright, 2007). In this study, we investigate civil service employees in Vietnamese government agencies regarding job demands and work exhaustion by applying the job demands-resources theory (Bakker et al., 2007) to predict career disappointment and turnover in the public service sector. Since job satisfaction enhances commitment and retention of employees (Lee et al., 2006), many studies have indicated the significant relationship between job satisfaction and turnover intention (Chan \& Ao, 2019; Falkenburg \& Schyns, 2007; Hom \& Griffeth, 1991; Lacity, Iyer, \& Rudramuniyaiah, 2009). Our study also considers job satisfaction as a predictor of turnover intention. Although social support acts as an essential resource for dealing with job-related stress, there have been few empirical studies elucidating the relationship between social support and job satisfaction (Yuh \& Choi, 2017). To fulfill the research gap, this study explores the effect of social support on job satisfaction as well as how job satisfaction relates to turnover intention among civil service employees.

This paper examines the extent to which civil service employees' turnover intention relates to job demands, work exhaustion, and job satisfaction. Additionally, we consider the paths from job demands, social support, and job motivation to work exhaustion as well as social support and work exhaustion to job satisfaction. A structural equation modeling (SEM) approach is used to analyze the data survey from civil service employees living in Ho Chi Minh City, Vietnam. The introduction of this paper is followed by a review of previous literature, data collection methodology, results of data analysis, and critical discussions of theoretical and practical implications.

\section{Literature review}

\subsection{Work exhaustion, job demands, turnover intention}

Work exhaustion is described as the state of being physically and psychologically exhausted from continual emotional pressures that are the result of handling substantively complicated circumstances at work (Cordes \& Dougherty, 1993; Moore, 2000; Shim, Park, \& Eom, 2017). In previous studies, work exhaustion has been shown to cause employees' withdrawal behaviors and a lack of solidarity with their colleagues (Cordes \& Dougherty, 1993; J. Kim, 2015; Shim et al., 2017). Additionally, some studies have found that frontline public employees are likely to leave their job under excessive emotional exhaustion (Jackson \& Maslach, 1982; Jackson, Schwab, \& Schuler, 1986; S. Kim, 2005; S. Kim \& Wright, 2007). In other words, the greater an employees' emotional exhaustion, the less their intention to remain in their organization. Civil service employees are likely to be more sensitive to work exhaustion because a particular characteristic of their job is to "process" people (Huang, Chuang, \& Lin, 2003; Manlove \& Guzell, 1997; Shim et al., 2017). Thus, work exhaustion can be a critical determinant of turnover intention (Bertelli, 2006). It continues to be essential for the Vietnamese government to improve public service systems to enhance the provision of services to citizens. The job demands-resources (JD-R) model was developed by Bakker et al. (2007) and Evangelia Demerouti et al. (2001). The JD-R model is based on the demand-control model (DCM), which asserts that employees with high demands and low control at work tend to be more susceptible to stress than others. JD-R theory expands DCM by suggesting that there are more job resources besides control that can be buffered for several job demands and proposes the associations between job characteristics, work exhaustion, and turnover intentions (Shim et al., 2017). According to JD-R theory, job characteristics can be divided into job demands and job resources (McDowell et al., 2019; Shim et al., 2017). Job resources refer to social, psychological, physical, or organizational dimensions of the job that bestir progress, knowledge, and personal development, or are virtuous in work objective achievement, or minimize demands and the associated physiological or psychological expenditures (McDowell et al., 2019). For instance, social support, performance feedback, and self-determination constitute job resources. Job demands refer to the constant physical, cognitive, and emotional efforts of an employee in various physical, psychological, social, and organizational aspects of a job, which in turn relates to physiological cost (Bakker et al., 2007; McDowell et al., 2019). In other words, employees much bear a psychological burden as a result of job constraints such as work overload, role ambiguity, high work pressure, and excessive complaints from clients (Shim et al., 2017). This study follows the research of Shim et al. (2017), which adopts three components of job demands - role conflict, work overload, and red tape - that significantly affect turnover intention of civil service employees. Role conflict is generated from conflicting expectations of stakeholders-which involves community, clients, professional groups, and colleagues - and conflicting role demands (Shim et al., 2017). In particular, civil service employees often have to deal with various inconsistent expectations from their agencies, stakeholders, and citizens that bring about paradoxical circumstances. Consequently, the complexity and conflicts may lead to ambiguous role expectations for civil service employees. Hence, it is frontline civil employees who often experience role conflict that may increase their turnover intention (Shim et al., 2017). According to Altaf and Awan (2011), conditions that characterize work overload consist of long working hours, pressure to work overtime, fewer holidays or breaks, unreasonable workload, and improbable expectations of what can be achieved in a given amount of time and with available resources. Sources of work overload include working conditions (excessive workload, the difficulty of tasks, working overtime), individual perceptions, or workplace orientation (Shim et al., 2017). "Red tape" is defined by Bozeman (2000) as rules, regulations, and procedures that are compulsory and result in a compliance burden that does not progress the legitimate purposes that the rules are determined to serve. Therefore, Shim et al. (2017) suggest that there should be apparent differentiation between bureaucratic red tape and organizational rules proposed for ensuring accountability and responsibilities of civil service employees. In fact, red tape is likely to be perceived as a dysfunction of bureaucracy (Moynihan \& Pandey, 2007). Moreover, extreme bureaucratic red tape may increase stress and fatigue of employees resulting from a low level of control and discretion in their working process (Giauque et al., 2012). A 
previous study by Khan, Quratulain, and Crawshaw (2013) indicates that local government employees usually have intention to leave their organization due to low aspirations and feeling disengaged from the organization under excessive red tape.

In general, previous studies have revealed that turnover intention of civil service employees is significantly affected by job demands encompassing work overload, role conflict, and red tape, which is correlated with work exhaustion in the public sector. Furthermore, the link between job demands and turnover intention has been emphasized by current studies, with results indicating that government employees may suffer emotional exhaustion in the context of high work demands (Kim \& Kim, 2005; Kim \& Wright, 2007), thus increasing the tendency to leave their job due to the inconsistency between the job and their intrinsic needs and personal values (Shim et al., 2017). Therefore, we propose the following hypotheses:

H1. Job demands are positively associated with work exhaustion.

H2. Job demands are positively associated with turnover intention.

H3. Work exhaustion is positively associated with turnover intention.

\subsection{Job motivation and social support}

Several definitions of social support have been conceptualized with different perspectives and circumstances. Social support is described by Cobb (1976) as a clue to developing one's belief of being cared for and loved, esteemed, and belonging to a network of mutual obligations. Hirsch (1981) posits that social support is established by other people when it comes to interpersonal relationships. According to Vangelisti (2009), social support can be defined from three perspectives: sociology, psychology, and communication. The first perspective focuses on the level of integration of an individual in a social group, while the second perspective concerns perceived support that is available, and the third perspective is chiefly about the relations between providers and recipients of support. Moreover, different categories such as emotional, appraisal, and instrumental support and sources such as supervisors, colleagues, or friends lead to diverse concepts of social support (J. Kim, 2015). Social support within an organization involves mutual information, resources, and emotional help from supervisors and coworkers (Aggarwal-Gupta et al., 2010; J. Kim, 2015). In particular, a great extent of social support, which is recognized by employees as sufficient available resources and the harmonized engagement with colleagues that comes from both supervisors and colleagues, could enhance satisfaction. Similar to the previous study, this study employs social support with two sources: supervisor support and colleague support. Job motivation is categorized into extrinsic motivation, which refers to conducting an act to achieve the enjoyment of doing it, and intrinsic motivation, which is conducting an act because of its instrumental value and innate satisfaction (Ryan \& Deci, 2000). In the study of Kim (2015), job motivation and social support were suggested to be predictors of employees' work exhaustion. In other words, high levels of job motivation would bring about less work exhaustion, and the more social support that organizations provide, the less work exhaustion will be created. Civil service employees may experience lower stress levels when their expectations share common goals with their organization (Giauque et al., 2012). In addition, as employees' resources are associated with their work conditions and personal values, job motivation and social support are considered as essential organizational resources (J. Kim, 2015). There is evidence from previous studies showing that lack of social support and job motivation could be potential stressors (Cropanzano \& Wright, 1998; Demerouti et al., 2001; Kim, 2015; Ikatrinasari et al., 2018; Qablan \& Farmanesh, 2019). Civil service employees would ultimately experience higher levels of work exhaustion as they perceive fewer emotional and social resources related to job motivation and social support (J. Kim, 2015). As a result, resources such as job motivation and social support could act as stressors associated with work exhaustion in the public sector. Therefore, we propose the following hypotheses:

H4. Social support is negatively associated with work exhaustion.

H5. Job motivation is negatively associated with work exhaustion.

Evidence from prior studies indicates that social support at the workplace would enhance both extrinsic and intrinsic motivation of employees (Tezci, Sezer, Gurgan, \& Aktan, 2015), which eventually results in higher performance and productivity (J. Kim \& Wiggins, 2011). Employees tend to feel more confident and positive working with supportive managers, as social support is crucial to unleashing positive energy among employees. Moreover, a significant correlation between social support and job motivation is found in previous findings. Therefore, we propose the following hypothesis:

H6. Social support is positively associated with job motivation.

\subsection{Job satisfaction}

Various concepts of job satisfaction have been proposed and drawn significant attraction from many studies in organizational psychology and management. Job satisfaction is defined as "the pleasurable emotional state resulting from the appraisal of one's job as achieving or facilitating the achievement of one's job values." (Locke, 1969, p.316). Job satisfaction involves external aspects (e.g., work conditions) and internal aspects (e.g., employee's career expectations). Consistent results from previous studies indicate that emotional exhaustion related to work exhaustion could decrease job satisfaction (McDowell et al., 2019; Mulki, Jaramillo, \& Locander, 2006; Rutherford et al., 2009). In particular, employees may find dissatisfaction with their jobs when they suffer work exhaustion due to excessive workload, working overtime, or difficult tasks. Therefore, we propose the following hypothesis: 
H7. Work exhaustion is negatively associated with job satisfaction.

Job satisfaction is considered an emotional orientation of employees toward their job (Price, 2001); they feel satisfied when their job provides them with desired conditions. It has also been shown that higher levels of satisfaction lead to better conditions both physically and mentally (Gelard \& Rezaei, 2016), which could be reinforced by high levels of motivation. Hence, it can be said that job motivation is a potential driver of job satisfaction, as job motivation is built up by both internal and external factors that could be important in identifying job satisfaction. Therefore, we propose the following hypothesis:

H8. Job motivation is positively associated with job satisfaction.

The significant relationship between social support and job satisfaction among employees at work has been demonstrated in several studies (Mintz-Binder, 2014). When employees receive sufficient social support, their job satisfaction is enhanced, which means they are more likely to provide better service with high-quality outcomes. However, the link between social support and job satisfaction may vary depending on the particular job characteristics or aspects of social support emphasized. For example, a previous study shows that among four types of social support - career mentoring, task support, coaching, and collegial support - career mentoring and task support are the two most important predictors of job satisfaction (Harris, Winskowski, \& Engdahl, 2007). Support from supervisors and colleagues was found to be positively associated with job satisfaction among police officers in New Zealand (Brough \& Frame, 2004). In addition, supervisor support acts as a strong predictor of job satisfaction and an indirect predictor of turnover intention. It can be said that employees who are dissatisfied with their jobs tend to consider leaving their organization (Yuh \& Choi, 2017). Based on previous studies, we propose the following hypotheses:

H9. Social support is positively associated with job satisfaction.

H10. Job satisfaction is negatively associated with turnover intention.

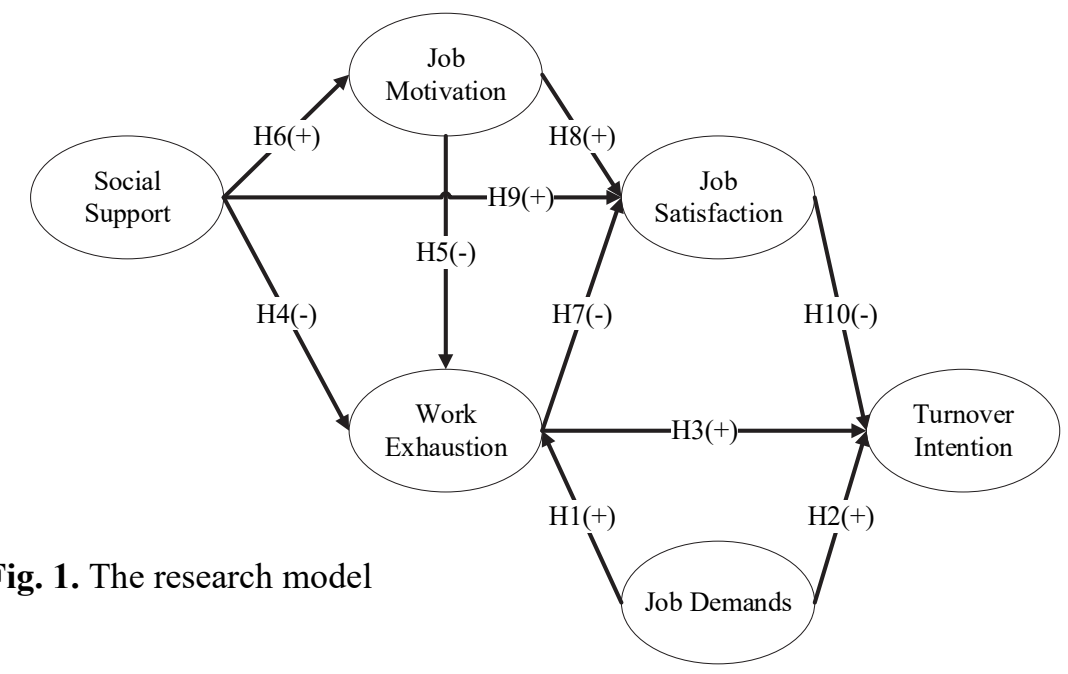

\section{Methodology}

\subsection{Data collection}

In this study, respondents are civil service employees working at government agencies in Ho Chi Minh City in Vietnam using a self-administered survey method and convenience sampling approach. The questionnaire consists of three main parts: purpose of survey, demographic information, and 33 measurement items. It took three months, from February to April, 2020, to complete data collection, which included two phases: a pilot test and the official survey. In the first phase, 30 samples were collected for reliability analysis using SPSS 20.0 software to ensure a reliable and comprehensive measurement scale. Based on the results of the pilot test, we slightly adjusted the wording to adapt to the Vietnam context before starting the second phase. An official survey with 400 questionnaires was conducted and delivered to 10 different departments in various fields within the public sector, such as the Department of Planning and Investment, the Department of Natural Resources and Environment, the Department of Construction, the Department of Finance, and the Department of Science and Technology. Among the distributed questionnaires, 329 were completed, demonstrating a return rate of $82.25 \%$. After eliminating 11 invalid samples, a final sample size of 318 was used for hypothetical testing.

\subsection{Measurement}

All of the scales in our study are adapted from previous studies in which six constructs are measured using a five-point Likert scale from 1 (Strongly Disagree) to 5 (Strongly Agree). The category of social support includes 12 items from J. Kim (2015) in which nine items measure supervisory support and three items measure colleague support. Seven items are used for job 
motivation, which is adapted from previous studies (J. Kim, 2015; Ryan \& Deci, 2000), including extrinsic motivation and intrinsic motivation, measured by three items and four items respectively. Turnover intention is measured via four items, job demands are measured via three items, and work exhaustion is measured via two items, which are all adapted from Shim et al. (2017). Job satisfaction is addressed via five items following former studies (Chan \& Ao, 2019; Seashore, Lawler III, Mirvis, \& Cammann, 1983). Table A in appendix presents the measurement scale.

\section{Results}

\subsection{Demographic information}

Table 1 shows four aspects of demographic information of respondents: gender, age, education level, and position in the organization. More than half of respondents are male (51.6\%); 48.4\% are female. Respondents' ages are divided into three groups: over 45, from 36 to 45 , and under 35, the percentage of which are $45.6 \%, 36.2 \%$, and $18.2 \%$, respectively. Of the 318 respondents, $68.9 \%$ have a bachelor's degree and $27.7 \%$ have higher academic qualifications. With regard to position, $87.1 \%$ of respondents are employees and $12.9 \%$ managers.

Table 1

Demographic Information

\begin{tabular}{|c|c|c|}
\hline \multicolumn{2}{|c|}{ Characteristics } & \multirow{2}{*}{$\frac{\text { Percentage }(\%)}{51.6}$} \\
\hline \multirow{2}{*}{ Gender } & Male & \\
\hline & Female & 48.4 \\
\hline \multirow{3}{*}{ Age } & Over 45 & 45.6 \\
\hline & $36-45$ & 36.2 \\
\hline & Under 35 & 18.2 \\
\hline \multirow{5}{*}{ Education level } & Graduate & 27.7 \\
\hline & Undergraduate & 68.9 \\
\hline & Vocational school & 1.6 \\
\hline & High school & 0.9 \\
\hline & Other & 0.9 \\
\hline \multirow{2}{*}{ Position } & Managers & 12.9 \\
\hline & Employees & 87.1 \\
\hline
\end{tabular}

\subsection{Reliability analysis}

First, we conducted a reliability test by calculating Cronbach's alpha coefficients and exploratory factor analysis (EFA) using SPSS 20.0 software. Cronbach's alpha reliability score is recommended to be greater than 0.7 (Hair et al., 2010).

Table 2

$\underline{\text { Reliability Analysis Results }}$

\begin{tabular}{|c|c|c|c|c|}
\hline \multicolumn{2}{|c|}{ Constructs } & Items & Factor loadings & Cronbach's alpha \\
\hline \multirow{5}{*}{\multicolumn{2}{|c|}{ Job Satisfaction }} & JS1 & 0.850 & \multirow{5}{*}{0.924} \\
\hline & & $\mathrm{JS} 2$ & 0.900 & \\
\hline & & JS3 & 0.891 & \\
\hline & & JS4 & 0.687 & \\
\hline & & JS5 & 0.797 & \\
\hline \multirow{3}{*}{\multicolumn{2}{|c|}{ Turnover Intention }} & TI1 & 0.965 & \multirow{3}{*}{0.831} \\
\hline & & TI2 & 0.712 & \\
\hline & & TI3 & 0.701 & \\
\hline \multirow{10}{*}{ Social Support } & \multirow{7}{*}{ Supervisor support } & SS1 & 0.533 & \multirow{7}{*}{0.903} \\
\hline & & SS2 & 0.503 & \\
\hline & & SS3 & 0.515 & \\
\hline & & SS6 & 0.778 & \\
\hline & & SS7 & 0.890 & \\
\hline & & SS8 & 0.990 & \\
\hline & & SS9 & 0.576 & \\
\hline & \multirow{3}{*}{ Colleague support } & $\mathrm{CS} 1$ & 0.809 & \multirow{4}{*}{0.780} \\
\hline & & $\mathrm{CS} 2$ & 0.752 & \\
\hline & & CS3 & 0.569 & \\
\hline \multirow{3}{*}{\multicolumn{2}{|c|}{ Job Demands }} & JD1 & 0.760 & \\
\hline & & JD2 & 0.773 & \multirow[t]{2}{*}{0.796} \\
\hline & & JD3 & 0.710 & \\
\hline \multirow{2}{*}{\multicolumn{2}{|c|}{ Work Exhaustion }} & WE1 & 1.023 & \multirow{5}{*}{0.882} \\
\hline & & WE2 & 0.708 & \\
\hline \multirow{7}{*}{ Job Motivation } & \multirow{3}{*}{ Extrinsic motivation } & JM1 & 0.604 & \\
\hline & & JM2 & 0.897 & \\
\hline & & JM3 & 0.710 & \\
\hline & \multirow{4}{*}{ Intrinsic motivation } & JM4 & 0.646 & \multirow[t]{4}{*}{0.859} \\
\hline & & JM5 & 0.814 & \\
\hline & & JM6 & 0.874 & \\
\hline & & JM7 & 0.492 & \\
\hline
\end{tabular}


Results show that Cronbach's alpha coefficients of all constructs range from 0.780 to 0.924 , indicating good internal reliability. Furthermore, KMO Bartlett's test coefficient should be above 0.5 with a significance $<0.05$ and total variance explained $>50 \%$, while factor loadings are required to be at least 0.5 (Hair et al., 2010). In the results, the KMO coefficient is 0.865 with a significance of 0.00 and the total variance explained is $62.5 \%$, which meets the requirement. All factor loadings also satisfied the thresholds of 0.5 , excluding that of JM12 (0.492), which is below 0.5 but still acceptable for a sample size of 250 or greater according to Hair et al. (2010). During this step, three items were removed due to insufficient factor loadings: TI4, SS4, and SS5. Table 2 presents the results of the reliability analysis.

\subsection{Confirmation factor analysis}

Next, confirmation factor analysis (CFA) was conducted to determine fitness of the measurement model, which indicates the statistical significance of the proposed hypotheses, using AMOS 20.0 software. According to Hair et al. (1998), suggested indices of composite reliability (CR) are at least 0.7 and average variance extracted (AVE) is at least 0.5 . The results of CFA testing are illustrated in Table 3 , showing that all indices have met the minimum level.

\section{Table 3}

CFA Results

\begin{tabular}{lcc}
\hline Constructs & CR & AVE \\
\hline JS & 0.926 & 0.715 \\
TI & 0.854 & 0.662 \\
JD & 0.796 & 0.565 \\
WE & 0.884 & 0.793 \\
JM & 0.743 & 0.592 \\
SSP & 0.378 & 0.378 \\
\hline
\end{tabular}

Table 4

Model Fit Indices

\begin{tabular}{lcc}
\hline Model fit indices & Threshold & CFA \\
\hline $\mathrm{X} 2 / \mathrm{df}$ & $<3$ & 1.646 \\
$\mathrm{CFI}$ & $>0.90$ & 0.965 \\
RMSEA & $<0.05$ & 0.045 \\
PCLOSE & $>0.05$ & 0.836 \\
\hline
\end{tabular}

In addition, according to $\mathrm{Hu}$ and Bentler (1999), the normal chi-square ( $\chi 2 / \mathrm{df}$ ) should be below 3; a comparative fit index (CFI) greater than 0.9 is considered acceptable and greater than 0.95 is considered excellent; root mean square error of approximation (RMSEA) is considered moderate between 0.05 and 0.1 and considered good below 0.05 ; and PCLOSE should be above 0.05 . The findings from CFA illustrate that the model fit indices $(\chi 2 / \mathrm{df}=1.646 ; \mathrm{CFI}=0.930 ; \mathrm{RMSEA}=0.045 ;$ and PCLOSE $=0.836)$ demonstrate the acceptable validity of the measurement model. Table 4 shows that all model fit indices are acceptable.

\subsection{Structural equation modeling}

In general, most of the proposed hypotheses are accepted, except for the negative effect of social support and job motivation on work exhaustion (H4 and H5) and the association between social support and job satisfaction (H9). The coefficients of job demands to work exhaustion and turnover intention are 0.619 and 0.297 , respectively, meaning that $\mathrm{H} 1$ and $\mathrm{H} 2$ are supported. The results also show that $\mathrm{H} 3$ and $\mathrm{H} 10$ are significant; the coefficients of work exhaustion and job satisfaction to turnover intention are 0.163 and -0.441 , respectively. Moreover, the effect of social support on job motivation is the strongest relationship, while the negative association between work exhaustion and job satisfaction is the weakest one, with corresponding coefficients of 0.749 and -0.150 , respectively, supporting H6 and H7. Lastly, H8, which states that job motivation has considerable impact on job satisfaction, is strongly supported, with the estimated coefficient of 0.647. All hypotheses testing results are presented in Table 5 and Figure 2.

\section{Table 5}

Hypotheses Results

\begin{tabular}{llccccc} 
& \multicolumn{1}{c}{ Hypothesis } & Estimate & SE & CR & P & Result \\
\hline H1 & Job demands are positively associated with work exhaustion & 0.619 & 0.074 & 8.321 & $* * *$ & Accepted \\
H2 & Job demands are positively associated with turnover intention & 0.297 & 0.077 & 3.866 & $* * *$ & Accepted \\
H3 & Work exhaustion is positively associated with turnover intention & 0.163 & 0.071 & 2.281 & $* *$ & Accepted \\
H4 & Social support is negatively associated with work exhaustion & -0.105 & 0.179 & -0.586 & 0.558 & Rejected \\
H5 & Job motivation is negatively associated with work exhaustion & -0.022 & 0.171 & -0.129 & 0.897 & Rejected \\
H6 & Social support is positively associated with job motivation & 0.749 & 0.108 & 6.959 & $* * *$ & Accepted \\
H7 & Work exhaustion is negatively associated with job satisfaction & -0.150 & 0.040 & -3.725 & $* * *$ & Accepted \\
\hline H8 & Job motivation is positively associated with job satisfaction & 0.647 & 0.168 & 3.842 & $* * *$ & Accepted \\
H9 & Social support is positively associated with job satisfaction & 0.197 & 0.152 & 1.295 & 0.195 & Rejected \\
H10 & Job satisfaction is negatively associated with turnover intention & -0.441 & 0.067 & -6.635 & $* * *$ & Accepted \\
\hline
\end{tabular}

Notes: $* * *$ p-value $<0.001 ; * *$ p-value $<0.05$ 


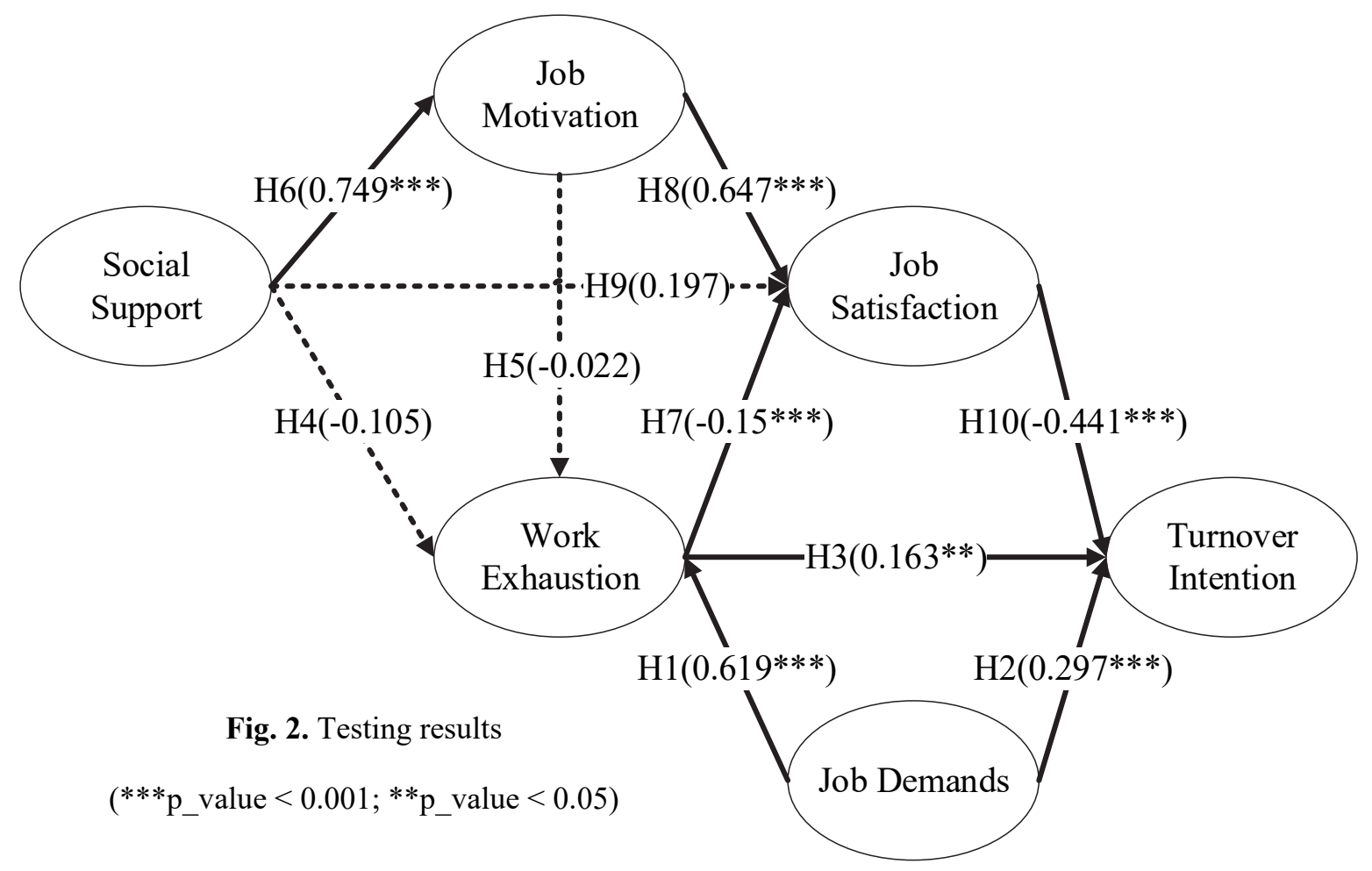

\section{Discussions}

Our study aims to explore the interrelation of job demands, work exhaustion, and turnover intention as well as the extent to which social support, job motivation, and job satisfaction are related and their effect on turnover intention among Vietnamese civil service employees. Several findings are revealed with both theoretical and practical implications.

First, the results of job demands related to work exhaustion and turnover intention are consistent with the previous study of Shim et al. (2017), in which the impact of job demands on work exhaustion is more dominant compared to its impact on turnover intention. This implies that high job-demand levels could result in significantly high levels of burnout while moderately affecting leaving intention of civil service employees. Additionally, the relationship between work exhaustion and turnover intention is also evidenced, meaning that high levels of stress and burnout could lead civil service employees to leave their jobs. Second, job motivation is strongly influenced by job satisfaction, which aligns with many previous studies (Gelard $\&$ Rezaei, 2016). The negative association between work exhaustion and job satisfaction is also supported, which aligns with McDowell et al.'s (2019) study; however, it is not a strong relationship but rather a moderate one. It is important for managers and organizations to keep motivating their employees as well as reducing the extent of burnout in order to maintain their engagement and satisfaction with their job. Third, similar to the finding of J. Kim (2015), the negative effects of social support and job motivation on work exhaustion are not significant. Perhaps Vietnamese civil service employees do not regard social support and job motivation as psychological or affective resources associated with levels of stress or burnout that could significantly reduce turnover intention.

Further, social support is found to be strongly associated with job motivation, in line with many previous studies (Sarwar \& Khalid, 2015; Tezci et al., 2015), which is the strongest relationship in the results. The availability of organizational resources, including the support of supervisors and co-workers, could significantly enhance motivation among employees, which may in turn increase their satisfaction and performance. However, in contrast to Yuh and Choi's (2017) findings, social support, including supervisor and colleague support, is insignificantly related to job satisfaction. Perhaps, similar to the influence on work exhaustion, social support, which is considered an emotional resource, does not relate to job satisfaction among civil service employees in Vietnam. It is worth noting that social support has only an indirect effect on job satisfaction through its impact on job motivation. Finally, the negative association between job satisfaction and turnover intention is significant, as expected, which means that greater levels of satisfaction result in diminishing intention to leave the organization of civil service employees.

\section{Conclusions and implications}

\subsection{Conclusions}

In summary, there are four key points in this study. First, job demands have a positive association with both work exhaustion and turnover intention. It is noteworthy that the lower job demands are, the less psychological burden civil service employees 
have to endure, and the lower the likelihood that they would leave their jobs. Therefore, the role of government is very essential in figuring out and implementing appropriate rules and policies to control such factors as role conflict, work overload, and red tape, which are obstacles that public employees often must address in their daily work. In practice, one common problem in Vietnam is that civil service employees often work in a position that does not fit their ability or expertise, leading to weak performance and low motivation; eventually, leaving the organization is their only option. Therefore, it is recommended that local government agencies address employee benefits in terms of working environment, salary and bonus policies, and career development to retain employees in the long term. By improving the working benefits, civil service employees may not only alleviate work exhaustion but also feel more engaged with their organization, thus decreasing their turnover intention and improving their job satisfaction.

Second, negative correlations of social support and job motivation on work exhaustion are insignificant, indicating that Vietnamese civil service employees do not associate emotional or affective resources with levels of burnout. A possible explanation for the existence of work exhaustion, even when support from others and motivation are available, is that an employee's working position itself does not meet the employee's expectations. As a result, when it comes to job demands, the employee tends to find them more difficult and exhausting. A periodic survey regarding employees' expectations should be conducted to provide insight into their jobs and make the proper adjustments if needed. Surprisingly, although social support has no impact on job satisfaction, its impact on job motivation is significant. It can be inferred that civil service employees appreciate emotional resources relating to positive emotion (e.g., motivation) rather than negative emotion (e.g., work exhaustion) and that social support only has an indirect effect on job satisfaction through job motivation. Another suggestion is that a harmonized working environment, engagement among employees, and attention from supervisors are necessary to motivate civil service employees through activities such as daily communications, mutual support, occasional team-building, or trips. Additionally, more encouragement on innovative ideas should be considered with less complicated processes, from acceptance to the implementation phase, which significantly relies on the support of colleagues and supervisors. In particular, government effort toward improving policies is the most essential factor in creating an innovative workplace.

Third, diminishing work exhaustion and enhancing job motivation are useful ways to increase job satisfaction. In other words, managers and organizations should pay attention to the mental health of their employees by providing support, advice, and encouragement whenever necessary. Fourth, regarding minimizing turnover intention among employees, local governments need to focus on tackling obstacles such as role conflict, work overload, and red tape. For example, the roles and accountabilities of civil service employees should be clearly stated, a more proper and balance workload should be taken into consideration, and working procedures and processes should be continuously improved to lessen bureaucratic red tape. In addition to job demands, decreasing work exhaustion or burnout along with maintaining high satisfaction could keep civil service employees with organizations.

\subsection{Implications}

Based on theoretical highlights, our study suggests some managerial implications that could be applied in the Vietnamese public sector. Some common problems that civil service employees face include pressure in daily tasks, working conditions, and motivational factors, while government agencies' problems include the high rate of turnover intention of their employees, which creates an unreplaceable gap for the organization regarding the quality of public service, costs for training new employees, and related costs. For instance, many professional fields in the public sector require highly qualified and highly professional employees, such as customs officials, inspectors, tax auditors, or price appraisers. Finding new employees with equivalent qualifications to replace these positions is very difficult because their professional activities do not simply follow a simple administrative process but require intensive levels of training, specialized knowledge, and practical experience. In addition, some fields require professional training and retraining to receive or renew a practicing certificate or to be appointed to the rank. Thus, it takes enormous resources to retrain new employees when being transferred. Other factors that directly lead to turnover decisions are work exhaustion, few opportunities for career development, inadequate remuneration, unacknowledged contributions and performances, unwholesome working environment and culture, or more attractive available jobs. Therefore, government agencies must take the initiative in making their jobs more appealing to attract and keep talent. Our suggestions to solve the current problems include improving three aspects: working environment, working and salary policies, and career development. First, it is necessary to establish more simple and compact administrative procedures and working process. The support regime and reformation of administrative procedures can boost civil service employees' performance and motivation, making the settlement of administrative procedures of citizens and organizations more convenient and efficient with fewer costs. Next, the salary and benefits regime should be formulated with specific criteria to ensure transparency and retain public employees within government agencies. It is essential to have an appropriate regime for remuneration as well. Recommendations on a remuneration regime can include official residences, travel allowances, or wage increases ahead of schedule. In addition to policies on physical support, policies on job rotation should be a focus, which may mean rotating back to an original position when a rotation period expires and giving priority to study abroad to improve qualifications; public employees whose families have difficult circumstances should be exempted from job rotation. In addition to a salary and remuneration regime, promotion and career development opportunities for civil employees should be carefully considered. Key performance index should be applied to evaluate and promote talent civil employees, and implement job rotation in the public sector. 


\section{Limitations}

Similar to most academic research studies, our study has some limitations that present opportunities for further research in the future. This study is limited in its sample size and by its specificity to Vietnam; thus, it lacks generalizability. As a result, future studies could expand their cultural backgrounds, countries, and sample size. Additionally, job demands are only explored in terms of three aspects (work overload, role conflict, red tape); therefore, additional demands should be included in the future. Lastly, further research should explore job performance among civil service employees instead of turnover intention to better understand their performance and enhance their work outcomes.

\section{Acknowledgment}

This research is funded by Vietnam National University Ho Chi Minh City (VNU-HCM) under grant number B2020-28-02.

\section{References}

Aggarwal-Gupta, M., Vohra, N., \& Bhatnagar, D. (2010). Perceived organizational support and organizational commitment: The mediational influence of psychological well-being. Journal of Business \& Management, 16(2), 105-124.

Altaf, A., \& Awan, M. A. (2011). Moderating affect of workplace spirituality on the relationship of job overload and job satisfaction. Journal of Business Ethics, 104(1), 93-99.

Bakker, A. B., Hakanen, J. J., Demerouti, E., \& Xanthopoulou, D. (2007). Job resources boost work engagement, particularly when job demands are high. Journal of Educational Psychology, 99(2), 274-284.

Balfour, D. L., \& Neff, D. M. (1993). Predicting and managing turnover in human service agencies: A case study of an organization in crisis. Public Personnel Management, 22(3), 473-486.

Bertelli, A. M. (2006). Determinants of bureaucratic turnover Intention: Evidence from the department of the treasury. Journal of Public Administration Research and Theory, 17(2), 235-258. https://doi.org/10.1093/jopart/mul003

Bozeman, B. (2000). Technology transfer and public policy: a review of research and theory. Research Policy, 29(4-5), 627655.

Brough, P., \& Frame, R. (2004). Predicting police job satisfaction and turnover intentions: The role of social support and police organisational variables. New Zealand Journal of Psychology, 33(1), 8-18.

Chan, S. H. J., \& Ao, C. T. D. (2019). The mediating effects of job satisfaction and organizational commitment on turnover intention, in the relationships between pay satisfaction and work-family conflict of casino employees. Journal of Quality Assurance in Hospitality \& Tourism, 20(2), 206-229.

Cobb, S. (1976). Social support as a moderator of life stress. Psychosomatic Medecine, 38(5), 300-314.

Cordes, C. L., \& Dougherty, T. W. (1993). A review and an integration of research on job burnout. Academy of Management Review, 18(4), 621-656.

Cropanzano, R., \& Wright, A. (1998). Emotional exhaustion as a predictor of job performance and voluntary turnover. Journal of Applied Psychology, 83(3), 486-493. https://doi.org/10.1037/0021-9010.83.3.486

Demerouti, E., Bakker, A. B., De Jonge, J., Janssen, P. P. M., \& Schaufeli, W. B. (2001). Burnout and engagement at work as a function of demands and control. Scandinavian Journal of Work, Environment and Health, 27(4), 279-286. https://doi.org/10.5271/sjweh.615

Falkenburg, K., \& Schyns, B. (2007). Work satisfaction, organizational commitment and withdrawal behaviours. Management Research News, 30(10), 708-723.

Gelard, P., \& Rezaei, S. (2016). The relationship between job motivation, compensation satisfaction and job satisfaction in employees of tax administration-A case study in Tehran. Asian Social Science, 12(2), 165-171.

Giauque, D., Ritz, A., Varone, F., \& Anderfuhren-Biget, S. (2012). Resigned but satisfied: The negative impact of public service motivation and red tape on work satisfaction. Public Administration, 90(1), $175-193$. https://doi.org/10.1111/j.1467-9299.2011.01953.x

Griffeth, R. W., \& Hom, P. W. (2001). Retaining valued employees. Sage Publications.

Hair, J.F., Anderson, R. E., Tatham, R. L., \& Black, W. C. (1998). Multivariate data analysis with readings (5nd ed.). Prentice-Hill, Upper Saddle River.

Hair, Joseph F, Anderson, R. E., Babin, B. J., \& Black, W. C. (2010). Multivariate data analysis: A global perspective (Vol. 7). Upper Saddle River, NJ: Pearson.

Harris, J. I., Winskowski, A. M., \& Engdahl, B. E. (2007). Types of workplace social support in the prediction of job satisfaction. The Career Development Quarterly, 56(2), 150-156.

Hirsch, B. J. (1981). Social networks and the coping process: Creating personal communities. In Social networks and social support. Sage Publications.

Hom, P. W., \& Griffeth, R. W. (1991). Structural equations modeling test of a turnover theory: Cross-sectional and longitudinal analyses. Journal of Applied Psychology, 76(3), 350-366.

House, J. S. (1983). Work stress and social support. Addison-Wesley Series on Occupational Stress.

Hu, L. T., \& Bentler, P. M. (1999). Cutoff criteria for fit indexes in covariance structure analysis: Conventional criteria versus new alternatives. Structural Equation Modeling, 6(1), 1-55. https://doi.org/10.1080/10705519909540118

Huang, I.-C., Chuang, C.-H. J., \& Lin, H.-C. (2003). The role of burnout in the relationship between perceptions off organizational politics and turnover intentions. Public Personnel Management, 32(4), 519-531. 
Ikatrinasari, Z., Prayogo, L., \& Ariyanti, S. (2018). Analysis of turnover intention power factors: A case study of retail company in Jakarta. Management Science Letters, 8(10), 1097-1102.

Jackson, S. E., \& Maslach, C. (1982). After-effects of job-related stress: Families as victims. Journal of Organizational Behavior, 3(1), 63-77.

Jackson, S. E., Schwab, R. L., \& Schuler, R. S. (1986). Toward an understanding of the burnout phenomenon. Journal of Applied Psychology, 71(4), 630-640.

Khan, A. K., Quratulain, S., \& Crawshaw, J. R. (2013). The mediating role of discrete emotions in the relationship between injustice and counterproductive work behaviors: A study in Pakistan. Journal of Business and Psychology, 28(1), 49-61.

Kim, H., \& Kim, W. G. (2005). The relationship between brand equity and firms' performance in luxury hotels and chain restaurants. Tourism Management, 26(4), 549-560.

Kim, J. (2015). What increases public employees' turnover intention? Public Personnel Management, 44(4), $496-519$.

Kim, J., \& Wiggins, M. E. (2011). Family-friendly human resource policy: is it still working in the public sector? Public Administration Review, 71(5), 728-739.

Kim, S. (2005). Factors affecting state government information technology employee turnover intentions. American Review of Public Administration, 35(2), 137-156. https://doi.org/10.1177/0275074004273150

Kim, S., \& Wright, B. E. (2007). IT employee work exhaustion: Toward an integrated model of antecedents and consequences. Review of Public Personnel Administration, 27(2), 147-170.

Kurniawaty, K., Ramly, M., \& Ramlawati, R. (2019). The effect of work environment, stress, and job satisfaction on employee turnover intention. Management Science Letters, 9(6), 877-886.

Lacity, M. C., Iyer, V. V., \& Rudramuniyaiah, P. S. (2009). Turnover intentions of indian IS professionals. Information Systems Outsourcing (Third Edition): Enduring Themes, Global Challenges, and Process Opportunities, $2004,393-421$. https://doi.org/10.1007/978-3-540-88851-2_18

Lee, Y., Nam, J., Park, D., \& Lee, K. A. (2006). What factors influence customer-oriented prosocial behavior of customercontact employees? Journal of Services Marketing, 20(4), 251-264.

Lipsky, M. (2010). Street-level bureaucracy: Dilemmas of the individual in public service. Russell Sage Foundation.

Locke, E. A. (1969). What is job satisfaction? Organizational Behavior and Human Performance, 4(4), 309-336.

Manlove, E. E., \& Guzell, J. R. (1997). Intention to leave, anticipated reasons for leaving, and 12-month turnover of child care center staff. Early Childhood Research Quarterly, 12(2), 145-167.

McDowell, W. C., Matthews, L. M., Matthews, R. L., Aaron, J. R., Edmondson, D. R., \& Ward, C. B. (2019). The price of success: balancing the effects of entrepreneurial commitment, work-family conflict and emotional exhaustion on job satisfaction. International Entrepreneurship and Management Journal, 15(4), 1179-1192.

Mintz-Binder, R. D. (2014). Exploring job satisfaction, role issues, and supervisor support of associate degree nursing program directors. Nursing Education Perspectives, 35(1), 43-48.

Moore, J. E. (2000). One road to turnover: An examination of work exhaustion in technology professionals. MIS Quarterly, 24(1), 141-168.

Moynihan, D. P., \& Pandey, S. K. (2007). The role of organizations in fostering public service motivation. Public Administration Review, 67(1), 40-53.

Mulki, J. P., Jaramillo, F., \& Locander, W. B. (2006). Emotional exhaustion and organizational deviance: Can the right job and a leader's style make a difference? Journal of Business Research, 59(12), 1222-1230.

Price, J. L. (2001). Reflections on the determinants of voluntary turnover. International Journal of Manpower, 22(7), 600624.

Prottas, J. M. (1978). The power of the street-level bureaucrat in public service bureaucracies. Urban Affairs Quarterly, 13(3), 285-312.

Qablan, N., \& Farmanesh, P. (2019). Do organizational commitment and perceived discrimination matter? Effect of SR-HRM characteristics on employee's turnover intentions. Management Science Letters, 9(7), 1105-1118.

Rutherford, B., Boles, J., Hamwi, G. A., Madupalli, R., \& Rutherford, L. (2009). The role of the seven dimensions of job satisfaction in salesperson's attitudes and behaviors. Journal of Business Research, 62(11), 1146-1151.

Ryan, R. M., \& Deci, E. L. (2000). Intrinsic and extrinsic motivations: Classic definitions and new directions. Contemporary Educational Psychology, 25(1), 54-67.

Sarwar, A., \& Khalid, S. (2015). Perceived social support and work motivation of day and night shift nurses. Pakistan Armed Forces Medical Journal, 65(2), 257-261.

Seashore, S. E., Lawler III, E. E., Mirvis, P. H., \& Cammann, C. E. (1983). Assessing organizational change: A guide to methods, measures, and practices. John Wiley \& Sons Inc.

Shim, D. C., Park, H. H., \& Eom, T. H. (2017). Street-level bureaucrats' turnover intention: does public service motivation matter? International Review of Administrative Sciences, 83(3), 563-582.

Tezci, E., Sezer, F., Gurgan, U., \& Aktan, S. (2015). A study on social support and motivation. The Anthropologist, 22(2), 284-292.

Vangelisti, A. L. (2009). Challenges in conceptualizing social support. Journal of Social and Personal Relationships, 26(1), 39-51.

Weissert, C. S. (1994). Beyond the organization: The influence of community and personal values on street-level bureaucrats' responsiveness. Journal of Public Administration Research and Theory, 4(2), 225-254.

Wright, B. E., \& Kim, S. (2004). Participation's influence on job satisfaction: The importance of job characteristics. Review 
of Public Personnel Administration, 24(1), 18-40.

Yuh, J., \& Choi, S. (2017). Sources of social support, job satisfaction, and quality of life among childcare teachers. The Social Science Journal, 54(4), 450-457.

Appendix A. Measurement scale

\begin{tabular}{|c|c|c|c|c|}
\hline \multicolumn{2}{|c|}{ Variables } & \multicolumn{2}{|r|}{ Items } & Sources \\
\hline \multirow{5}{*}{\multicolumn{2}{|c|}{ Job Satisfaction }} & JS1 & My job is like a hobby to me & \multirow[t]{5}{*}{ Chan and Ao, (2019) } \\
\hline & & JS2 & My job is usually interesting enough to keep me from getting bored & \\
\hline & & JS3 & I feel fairly well satisfied with my present job & \\
\hline & & JS4 & I feel that I am happier in my work than most other people & \\
\hline & & JS5 & Most days I am enthusiastic about my work & \\
\hline \multirow{4}{*}{\multicolumn{2}{|c|}{ Turnover Intention }} & TI1 & As soon as I find another job, I will leave this job. & \multirow[t]{4}{*}{ Shim et al. (2017) } \\
\hline & & TI2 & If I were completely free to choose, I would change to a different profession & \\
\hline & & TI3 & I often think about quitting my job. & \\
\hline & & TI4 & I feel used up at the end of the workday & \\
\hline \multirow{12}{*}{$\begin{array}{l}\text { Social } \\
\text { support }\end{array}$} & \multirow{9}{*}{$\begin{array}{l}\text { Supervisor } \\
\text { support }\end{array}$} & SS1 & My supervisor takes the time to learn about my career goals and aspirations. & \multirow[t]{12}{*}{ J. Kim (2015) } \\
\hline & & $\mathrm{SS} 2$ & My supervisor cares about whether or not I achieve my career goals. & \\
\hline & & SS3 & $\begin{array}{l}\text { My supervisor keeps me informed about different career opportunities for me in the } \\
\text { organization. }\end{array}$ & \\
\hline & & SS4 & $\begin{array}{l}\text { My supervisor makes sure I get the credit when I accomplish something substantial } \\
\text { on the job. }\end{array}$ & \\
\hline & & SS5 & My supervisor gives me helpful feedback about my performance. & \\
\hline & & SS6 & $\begin{array}{l}\text { My supervisor gives me helpful advice about improving my performance when I } \\
\text { need it. }\end{array}$ & \\
\hline & & SS7 & $\begin{array}{l}\text { My supervisor supports my attempts to acquire additional training or education to } \\
\text { further my career. }\end{array}$ & \\
\hline & & SS8 & $\begin{array}{l}\text { My supervisor provides assignments that give me the opportunity to develop and } \\
\text { strengthen new skills. }\end{array}$ & \\
\hline & & SS9 & $\begin{array}{l}\text { My supervisor assigns me special projects that increase my visibility in the organi- } \\
\text { zation. }\end{array}$ & \\
\hline & \multirow{3}{*}{$\begin{array}{l}\text { Colleague } \\
\text { support }\end{array}$} & CS1 & My peers feel there is value in attending training programs & \\
\hline & & CS2 & My peers feel that training adds no value. & \\
\hline & & CS3 & During the course, I learned a lot from other participants. & \\
\hline \multirow{3}{*}{\multicolumn{2}{|c|}{ Job Demands }} & JD1 & $\begin{array}{l}\text { Due to an excessive workload, it is increasingly difficult for me to concentrate on } \\
\text { my job assisting welfare recipients }\end{array}$ & \multirow[t]{3}{*}{ Shim et al. (2017) } \\
\hline & & JD2 & I have to face incompatible requests from two or more people in performing my job. & \\
\hline & & JD3 & $\begin{array}{l}\text { Due to too much administrative/bureaucratic procedure, it is increasingly difficult } \\
\text { for me to concentrate on my job assisting welfare recipients. }\end{array}$ & \\
\hline \multirow{2}{*}{\multicolumn{2}{|c|}{ Work Exhaustion }} & WE1 & I feel fatigued when I get up in the morning and have to face another day on the job & \multirow[t]{2}{*}{ Shim et al. (2017) } \\
\hline & & WE2 & I feel emotionally drained from my work. & \\
\hline \multirow[t]{7}{*}{$\begin{array}{l}\text { Job Mo- } \\
\text { tivation }\end{array}$} & \multirow[t]{3}{*}{$\begin{array}{l}\text { Extrinsic } \\
\text { Motivation }\end{array}$} & JM1 & $\begin{array}{l}\text { Because others will reward me financially only if I put enough effort in my job (e.g., } \\
\text { employer, supervisor ...) }\end{array}$ & \multirow[t]{7}{*}{$\begin{array}{l}\text { J. Kim (2015); Ryan } \\
\text { and Deci (2000) }\end{array}$} \\
\hline & & JM2 & $\begin{array}{l}\text { Because others offer me greater job security if I put enough effort in my job (e.g., } \\
\text { employer, supervisor ...). }\end{array}$ & \\
\hline & & JM3 & Because I risk losing my job if I don't put enough effort in it. & \\
\hline & \multirow{4}{*}{$\begin{array}{l}\text { Intrinsic } \\
\text { Motivation }\end{array}$} & JM4 & Because I personally consider it important to put efforts in this job & \\
\hline & & JM5 & Because putting efforts in this job aligns with my personal values. & \\
\hline & & JM6 & Because putting efforts in this job has personal significance to me & \\
\hline & & JM7 & Because I have to prove to myself that I can & \\
\hline
\end{tabular}


(C) 2020 by the authors; licensee Growing Science, Canada. This is an open access article distributed under the terms and conditions of the Creative Commons Attribution (CC-BY) license (http://creativecommons.org/licenses/by/4.0/). 